\title{
A VÁLLALATI TÁRSADALMI FELELŐSSÉGVÁLLALÁS (CSR) ÉS A MUNKAHELYI EGÉSZSÉGFEJLESZTÉS KAPCSOLATA
}

\author{
Molnár Anikó - Müller Anetta
}

\section{Összefoglalás}

Kutatásunkban az ország több pontjáról viæsgáltunk mikro-kis- közép-és nagyvállalatokat $(\mathrm{N}=41)$. Primer kutatásunkban mind kvalitativ, mind kvantitativ adatelem zést végeztünk, mely során kérdöiv és mélyinterjú került kidolgozásra annake érdekében, hogy képen kapjunk a hazánkban müködö vállalatok egészséges életmódra való törekvéséröl, az egészségfejlesz̨tö programok megjelenéséröl a vállalatokérdekében. Az eredmények alapján kiderült, hogy bár a vállalatok. lényeges tényezönek tartják az egészséges munkaeröt, munkakörnyezetet és fontosnak tartják. a sportolást, ežt még mindig az egyén saját feladatának tekintik, szervezeti szinten az egészségtudatossághoz. nem társul ilyen mértékü vállalati felelösségvállalás. A mélyinterjúkból kiderül, a vállalatok méretének növekedésével növekszilk az egészségfejlesztö kezdeményezések aktív alkalmazása is, melyhez a válaszadók szerint a foglalkoztatottak szemléletváltása is elengedhetetlen. A vállalatokat vélemény ük szerint leginkább az adófelhasználással és egyéb támogatásokkal segithetné elo" a kormányzat egészségfejlesztö törekvéseikben.

Kulcsszavak: munkahelyi egészségejlesztés, egészséges munkaerö, CSR, jóllét

JEL: Z2

\section{WORKPLACE HEALTH PROMOTION WITH REGARDS TO CORPORATE SOCIAL RESPONSIBILITY (CSR)}

\begin{abstract}
In our research, we examined micro, small, medium and large enterprises from several parts of the country $(N=$ 41). In our primary research, we performed both qualitative and quantitative data analysis, during which a questionnaire and in-depth interviews were created in order to get a picture of enterprises operating in Hungary in their effort regarding healthy lifestyle and the emergence of health promotion programs within the company. The results show that although companies consider a bealthy workforce, work environment and sport to be important, it is still considered an individual responsibility, and at the organizational level, health aware-ness is not associated with such corporate responsibility. In-depth interviews show that as the size of companies increases, so does the active use of health promotion initiatives, for which respondents say a change in the attitudes of employees is also essential. In their opinion, companies could be best helped by the government through their use of taxes and other subsidies in their health promotion efforts.
\end{abstract}

Keywords: workplace health promotion, healthy employees, CSR, well-being JEL: Z2 


\section{Bevezetés}

Napjainkban a társadalmi felelősségvállalás (CSR) a vállalatok küldetésében is egyre inkább jelen van, azonban az általános megítélés szerint a foglalkoztatottak egészsége még mindig egyéni felelősségként értékelt feladat. Igaz, hogy a humánerőforrás gazdálkodással sok kutatás foglalkozik, mely a munkaerőt, mint értéket, vagy a vállalat egyik meghatározó erőforrásaként nevesíti (Dajnoki, 2019; 2020; Héder et. al., 2018; Kozák - Dajnoki, 2019). Ezzel ellentétben a vállalatok társadalmi felelősségvállalása egyre inkább fókuszba kerül, annak a stratégiában betöltött szerepe egyre nagyobb prioritást kap (Ráthonyi-Odor et. al., 2017). Vannak olyan kutatások is, melyek az egyéni társadalmi felelősségvállalás lehetőségeit vetik fel a szabadidősport területén, amik az egészségmegőrzéshez járulhatnak hozzá (Gôsi et. al., 2020). Más kutatások felhívják a figyelmet arra, hogy a dolgozók és munkavállalók egészségfejlesztését célzó CSR igen fontos és hasznos az érintettek (vállalat, munkavállaló) számára (Staniškienè - Stankevičiūtè, 2018; Rahdari et. al., 2016; Holmqvist, 2009).

A szervezetek ugyanis felismerték, hogy mivel a vállalatuk mind ökológiai, mind társadalmi szempontból egy adott környezetben múködő összetett rendszer, ezért küldetésükbe a profitabilitás mellett érdemes az erkölcsi alapon nyugvó, kiegészítő törekvéseket is beépíteni. Ilyen kezdeményezés például a környezet és társadalomtudatosság, vagy a foglalkoztatottak egészségének szem előtt tartása. Ezek alapján elmondható, hogy a felelős vállalati koncepcióhoz szorosan beleillik az egészségvédelem és a sport, annak népszerűsítése, sportolási lehetőségek biztosítása, támogatása, melyet az egyén felelősségvállalás mellett vállalati szinten is kezelni szükséges (Ráthonyi-Odor et. al., 2017; Ráthonyi-Odor et. al., 2020).

A munkavállalók értékként jelennek meg, nem csak a társadalom, de a vállalkozások számára is, hiszen az egészséges munkaerő megtakarítást jelent a cégeknek, hiszen kevesebb a munkahelyi hiányzást és balesetet jelent, valamint produktívabbak is, melyek egyúttal a vállaltok versenyképességét is növelik. Így egyre több hazai és nemzet-közi kutatás foglalkozik a munkahelyi egészségfejlesztési programok megtérülésével, gazdasági hasznával a vállaltok számára (Aldana et. al., 2005; Baicker et. al., 2010; Nyitrainé-Garai 2015).

\section{Szakirodalmi áttekintés}

Napjainkban egyre több olyan kutatás jelenik meg, mely a sport CSR-ban való megjelenéséről (Bradish - Cronin, 2009; Levermore - Moore, 2015; Breitbarth et. al., 2015; Bason Anagnostopoulos, 2015), illetve a sportcsapatok által alkalmazott CSR-ról szól (Heinze et. al., 2014).

Az elmúlt évtizedekben nem csak a CSR de a munkahelyi egészségfejlesztés is egyre népszerúbb stratégiává vált a vállalatok körében, amelyen keresztül a szervezetek és más munkáltatók társadalmi felelősségvállalást gyakorolnak. Ez a kezdeményezés hozzájárul a munkavállalók jobb egészségéhet az egészséges életmódra való ösztönzéséhez és jólétéhez, ezáltal növelve a termelékenységet és csökkentve a betegséggel töltött napok számát. A CSR a munkahelyi egészségfejlesztésben hozzájárulhat a fenn-tartható és felelősségteljes szervezetek létrehozásához is. A vállalati társadalmi felelősségvállalás (CSR) bármely tevékenysége potenciálisan a szervezeti ellenőrzés kifejezésének tekinthető, amelyen keresztül a szervezet környezetének minden további aspektusát a szervezet cél- 
jainak és perspektíváinak kedvező módon hajtja végre. A „társadalmilag felelősségteljes”, pontosabban az „egészségfejlesztő” tevékenységek támogatásával a szervezetek hatékonyan végezhetnek egy alapvető feladatot, a környezet irányítását (Holmqvist, 2009).

A munkavállalók egészségének megőrzése és megtartása társadalmilag felelős tevékenységnek tekinthető abban az értelemben, hogy ezek a munkahelyi egészségfejlesztő programok támogatják a munkavállalókat egészségi állapotuk és jólétük javításában, ezáltal megvalósítva a társadalmi javulás törekvését. Másrészt az egészségfejlesztő programokkal megvalósuló CSR-1 egyfajta vállalati ellenőrzési mechanizmust is megvalósíthat, amelyek révén a szervezetek megpróbálnak számukra kedvezőbb munkavállalói viselkedést kialakítani az alkalmazottak és a környezetük más szereplői között, azaz olyan magatartást, amely jobban igazodik a vállalati normákhoz (Bjurvald, 2004; Tones - Tilford, 2001).

A munkahelyi egészségfejlesztés szerte a világban egyre fontosabb stratégiává válik, amelyen keresztül a munkáltatók megpróbálnak társadalmilag felelősségteljesen cselekedni annak érdekében, hogy a munkavállalók egészsége és szociális jó közérzete javuljon. A foglalkoztatottak egészségének megőrzésével és javításával olyan megtérülő beruházásba fektetnek a vállalkozások, mely csökkenti a betegségekből származtatható költségeket, mint a táppénzes napok száma, csökkenő termelékenységből adódó kiesések, fluktuáció stb. Számos nagy nemzetközi vállalat dolgozott ki sikeres munkahelyi egészségfejlesztési programot az „egészségtelen munkavállalói magatartás” kezelése érdekében. Jól ismert amerikai példák a Lockheed, az IBM, Johnson and Johnson, és a Ford Motor Company (Sidell et. al., 2003; Seedhouse, 2004) Az Európai Munkahelyi Biztonsági és Egészségvédelmi Ügynökség (The European Agency for Safety and Health at Work) (2004) jelentést készitett a munkahelyi egészségfejlesztés és a CSR közötti kapcsolatokról az Európai Unióban. A jelentés tizenegy olyan európai vállalatokról mutat be esettanulmányt, amelyek beépítették ezt az egészségfejlesztési tevékenységüket a CSR tevékenységükbe. A jelentés egyértelművé teszi, hogy „a jó munkavállalói egészség a vállalatok társadalmi felelősségi körébe tartozik, és a CSR szerves részének tekinthető.

\section{Anyag és módszer}

Kutatásunkban szekunder és primer elemzést egyaránt végeztünk. A hazai és nemzet-közi releváns szakirodalmak áttekintését követően kérdőívet és hozzá kapcsolódóan egy mélyinterjút állítottunk össze. A primer kutatás részeként kvantitatív és kvalitatív adatelemzést is végeztünk. A két formában a munkáltatói oldalról kívántuk megvizsgálni az egészségfejlesztő és sportprogramok meglétét a vállalatok életében. Kérdéseket tettünk fel többek közt a vállalatok alkalmazottjai munkájának jellegéről, a vállalatot képviselők megítélése szerint a munkahelyen fennálló egészségkárosító hatásokról. Az egészségfejlesztő programokról, azok CSR-ban elfoglalt helyérôl és az egészségfejlesztő hatások közvetett hatásának észleléséről (betegséggel töltött napok száma, vállalat hírneve, munkavállalók lojalitása stb.).

A kérdőíves kitöltések alapján összeállított adatbázis operatív elemzést az IBM SPSS statisztikai adatkezelő program segítségével végeztük el, melyben a leíró statisztikák domináltak.

A felmérés mélyinterjús adatait Atlas.ti kvalitatív adatelemző program segítségével dolgoztuk fel, mely során a vállalatokat méret szerinti csoportosításban kérdeztük jelenleg alkalmazott egészségfejlesztő tevékenységükről, jövőben megvalósítani tervezett törekvéseiről és arról milyen javaslatokkal élnének a kormányzat felé, melynek megvalósításával az állam segíthetné a munkáltatókat foglalkoztatottjaik egészséges életmódra való ösztönzésükben. 


\section{A minta bemutatása}

A kérdőívre és a mélyinterjúra 41 értékelhető kitöltés érkezett az ország több pontján múködő vállalatok köréből. A vállalatokat az ország több régiójából választottuk ki, hólabda mintavétellel, a könnyebb elérhetőség, illetve annak érdekében, hogy a mikro-, kis, közép és nagyvállalatok is képviseltessék magukat a mintában.

1. táblázat. A kérdőívben résztvevő vállalkozások megoszlása méret szerint

\begin{tabular}{|c|c|c|}
\hline Méret & Gyakoriság (db) & Százalék (\%) \\
\hline Mikrovállalat & 19 & 46,34 \\
\hline Kisvállalat & 8 & 19,51 \\
\hline Középvállalat & 6 & 14,63 \\
\hline Nagyvállalat & 8 & 19,51 \\
\hline Összesen & 41 & 100 \\
\hline
\end{tabular}

Az így beérkezett kitöltések alapján és a 2004. évi XXXIV. törvény a kis- és középvállalkozásokról, fejlődésük támogatásáról (netjogtar.hu, 2020) szóló törvényben meghatározott összes foglalkoztatottak létszáma, éves nettó árbevétel, illetve mérlegfőösszeg alapján a meg-fogalmazott kritériumok szerint a következő négy kategóriába sorolva a következő méret szerinti megoszlást kaptuk (1. táblázat).

A vezetőket ezen felül a vállalatok mûködési idejéről és az alkalmazottak munkájának jellegéről is kérdeztük. A 41 megkérdezett szervezet 34,1\% több, mint 20 éve, 31,7\% 10-20 éve, $22 \%$ 5-10 éve, $12,2 \%$ pedig kevesebb, mint 5 éve múködő vállalat. Ami pedig az alkalmazottak munkavégzésének jellegét illeti, a megkérdezettek többsége, 46,6\% tisztán fizikai munkát végző munkaerőt alkalmaz, 26,8 - 26,8\% pedig szellemi és szellemi, illetve fizikai munkát egyaránt végzô munkavállalókat foglalkoztat.

\section{Eredmények}

Annak érdekében, hogy a vállalatok egészséges életmódhoz való hozzáállását, vizsgáljuk Likertskála formában fogalmaztunk meg 11 db állitást, melyet 0-tól 5-ig értékelhettek a kitöltők, ahol 0 egyáltalán nem, 5 teljes mértékben egyetért az állítással.

Az értékelendő állítások három nagy dimenziót fednek le:

- Általános megállapítások a szervezetről, mint például: jelenlegi egészségfejlesztô programok fontossága, vagy az egészséges munkaerő fontossága;

- Egészségfejlesztő programok hatása a vállalatra, ahol olyan állításokat kellett értékelniük legjobb megítélésük szerint, mint például: Az egészségfejlesztő programok hatása a munkavállalók véleményére; azok lojalitására;

- Sportspecifikus állítások: mint a sportolás fontossága; sportolási lehetőség támogatása a cégen belül. 


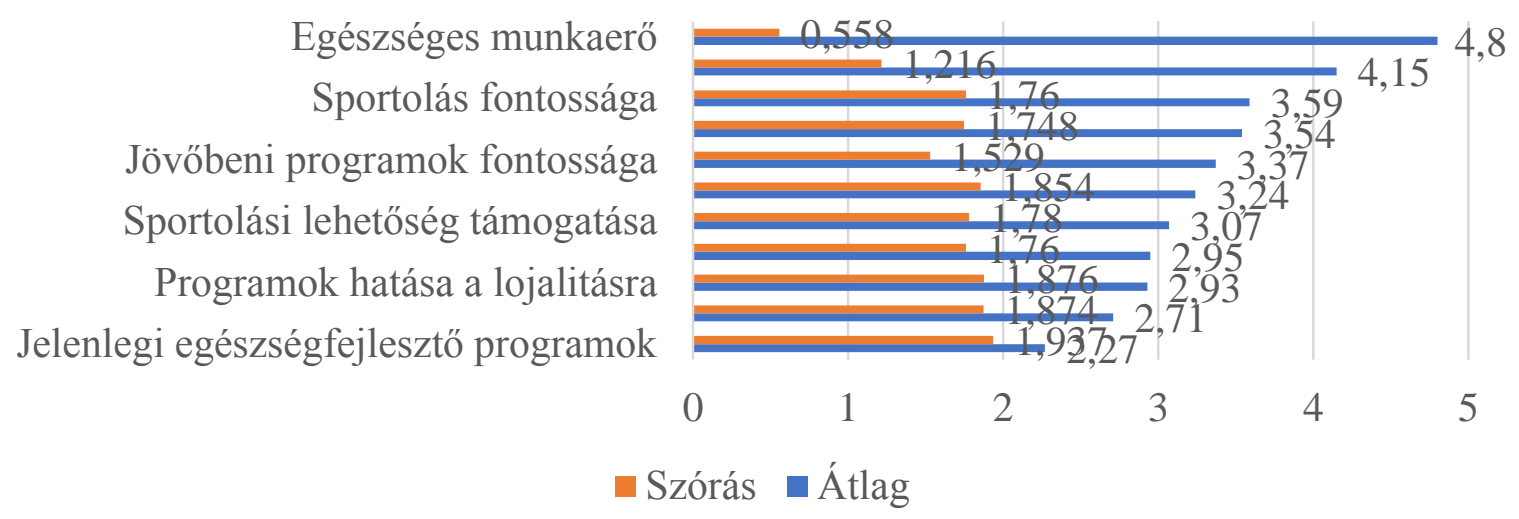

1. ábra. A vállalatok egészséges életmódhoz való hozzáállása, annak megítélése

A válaszokból kiderül (1. ábra), hogy bár a vállalatok képviselôi az egészséges munkaerőt, az egészséges munkakörnyezetet és a sportolást tartják a legfontosabb tényezőnek, a jelenlegi egészségfejlesztô programok jelentős mértékben elmaradnak ennek támogatásától (átlag: 2,27; szórás: 1,932). Ebből is jól látszik, hogy a cégek az egészséges életmódra való törekvést még mindig nem saját feladatuknak tartják. Ezt a sportolási lehetőségek támogatása is alátámasztja, mely szintén kevésbé fontos tényezőként van jelen a vállalatok életében (átlag: 3,07; szórás: 1,78). Pozitívumként értékelendő azonban, hogy a jövőbeni egészségfejlesztő programok már fontosabb prioritásként jelennek meg (átlag: 3,37; szórás: 1,53).

A munkáltatók szerint az egészségfejlesztô programok leginkább a munkavállalók véleményére vannak hatással, ezt követte a kieséssel és betegséggel töltött napok számának csökkenése. Megítélésük szerint az ilyen kezdeményezések legkevésbé a lojalitásra és a vállalat hírnevére vannak.

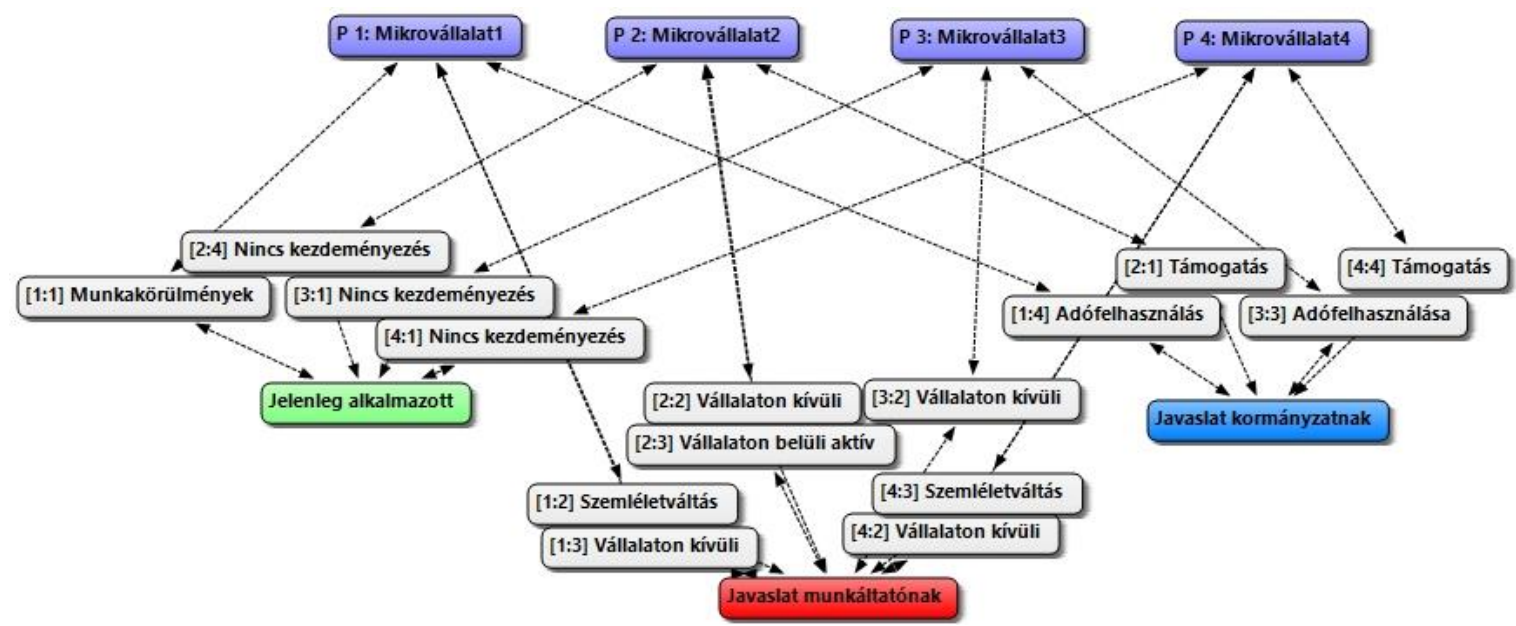

2. ábra. A mikrovállalatok körében jelenleg alkalmazott egészségfejlesztő program meglétének alakulása és az általuk megfogalmazott javaslatok a kormányzatnak és munkavállalóknak 
A mélyinterjúk elemzéséhez a négy csoportból véletlenszerűen kiválasztottunk 4 mikro- 4 kis-, 4 közép- és 4 nagyvállalatot, akiket a jelenleg alkalmazott egészségfejlesztő kezdeményezésekről kérdeztük, arról, hogy milyen további javaslataik lennének, amellyel a munkavállalóik egészséges életmódját segíthetnék elô vállalati szinten, illetve milyen javaslatokat intéznének a kormányzat felé, amelyek ezen célkitűzéseikben segítenék őket.

A mikrovállalatok közül kiválasztott négy szervezet megkérdezése után a következő képet kaptuk (2. ábra). A négy vizsgált vállalat közül csupán egy alkalmaz jelenlegi múködése során a munkavállalók egészségének javítására szolgáló kezdeményezést, azonban ez sem az alkalmazottak aktivitásának növelésére irányul, az első vállalat a munkakörülmények javítására helyezi a hangsúlyt.

A jövőbeni törekvéseknél már jelentős szerepvállalásra való törekvés figyelhető meg. Mind a négy vállalat az alkalmazottjai fizikai aktivitásának elősegítését tűzte ki célul, vállalaton belüli szervezett tornák, sportnapok, illetve vállalaton kívüli kezdeményezésekkel, melyek középpontjában a munkavállalók edzésének és sportolásának juttatásokkal való támogatása áll. Emellett a fizikai aktivitás támogatása mellett a minél szélesebb alkalmazotti bevonás és az egészségtudatosság növelése érdekében a szemléletváltás is fókuszba kerül. A megkérdezett mikrovállalatoknál négyből két szervezet is úgy gondolja, a sporttevékenységek támogatása nem elég, ezért az ilyen kezdeményezéseket egészségkampányokkal és tájékoztatókkal egészítenék ki.

A kormányzat felé intézett javaslatokban cégek úgy gondolják az állami szerepvállalás leginkább támogatásokkal és az adó egészségmegőrző területen való felhasználásával segíthetnék elő a cégeket a munkavállalók egészséges életmódjának való törekvésben.

A kisvállalatoknál (3. ábra) már csupán egy szervezet nyilatkozott úgy, hogy jelenleg semmilyen munkahelyi egészségfejlesztő kezdeményezést nem alkalmaznak az alkalmazottak magas fizikai aktivitása miatt (fizikai munkavégzés jellege). Ezen a szinten már a vállalaton belüli aktív (sportnapok, közös tornák szervezése) és a vállalaton belüli passzív (a cég létesítményt bérel) törekvések is jelen vannak, egy megkérdezett pedig úgy nyilatkozott jelenleg csak szóbeli javaslattétellel (Szemléletváltás) igyekeznek felhívni foglalkoztatottjaik figyelmét az egészséges életmód fontosságáról.

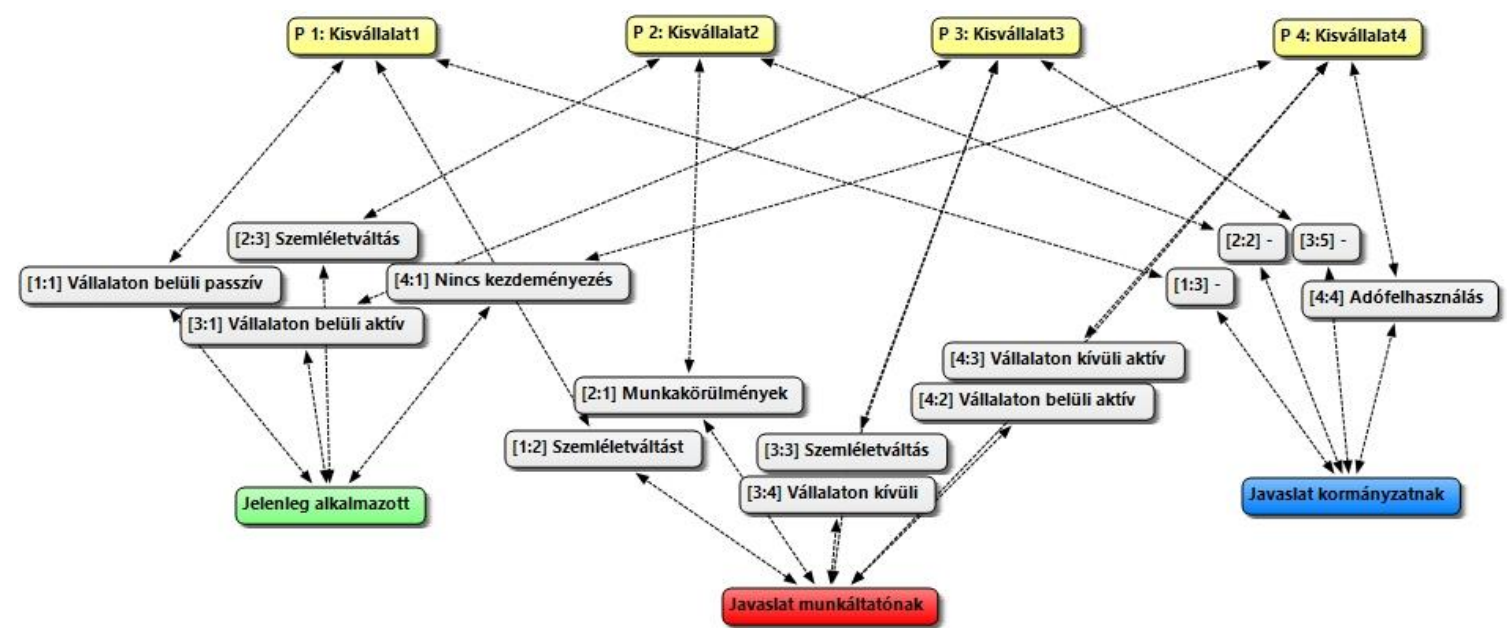

3. ábra. A kisvállalatok körében jelenleg alkalmazott egészségfejlesztő program meglétének alakulása és az általuk megfogalmazott javaslatok a kormányzatnak és munkavállalóknak

A jelenleg alkalmazott kezdeményezések és munkáltatói javaslatok összevetéséből kiderül, hogy azon cégek, akik vállalaton belüli intézkedéseket alkalmaznak (2. és 3. kisvállalat) úgy gondolják, 
hogy a programjaik, a cég által szervezett sportnapok és bérelt termek mellett szemléletváltással, egészségkampányokkal is támogatniuk és népszerűsíteniük kellene az életmódváltást alkalmazottjaik körében. Azon kisvállalatok, akik jelenleg is egészségfejlesztő tevékenységet folytatnak nem intéztek javaslatot a kormányzat felé.

A 4. kisvállalat, akiknél jelenleg nincs ilyen kezdeményezés vállalaton belüli sportnapokat, és vállalaton kívüli edzési lehetőségek támogatását vezetné be, kormányzat felé intézett javaslatuk szerint pedig az adó egészségmegőrző felhasználásával segítené leginkább elő a kormányzat a munkáltatók egészségfejlesztésre való törekvésükben.

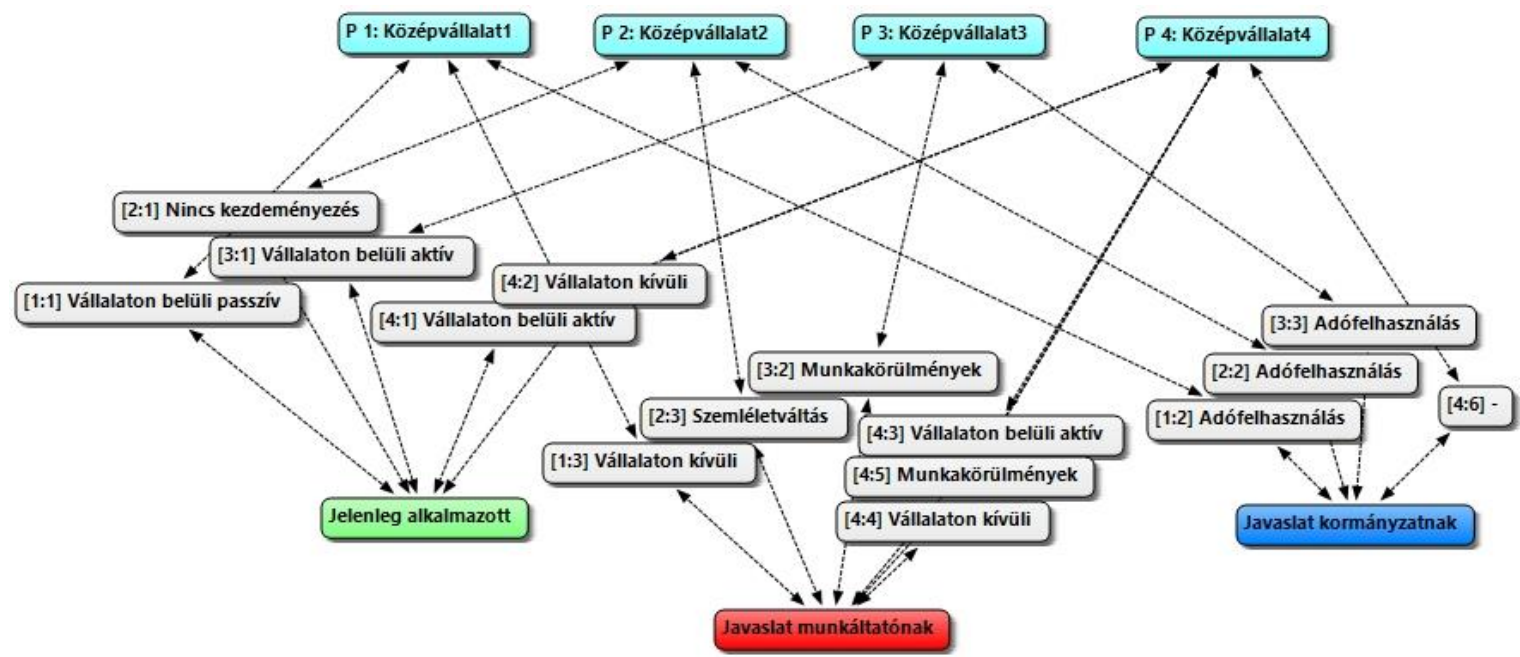

\section{4. ábra. A középvállalatok körében jelenleg alkalmazott egészségfejlesztő program meg- létének alakulása és az általuk megfogalmazott javaslatok a kormányzat-nak és munka- vállalóknak}

A középvállalatok közül kiválasztott négy szervezet interjúiban a fizikai aktivitást és a sportolási tevékenységekben való részvétel növelésére szolgáló kezdeményezések már aktívabb felelősségvállalást és céges egészségfejlesztő programot feltételeznek (4. ábra). Ezen a szinten a jövőbeni javaslatoknál már a munkakörülmények javítása is a figyelem középpontjába kerül, szintén megjelenik a szemléletváltást elősegítő egészséges életmódot népszerűsítő kampányok és a munkavállalók vállalaton kívüli ösztönzése is juttatások által.

A kormányzat felé intézett javaslatok többsége itt is az adófelhasználást tartja megoldásnak az állami szintű egészségfejlesztésben.

A megkérdezett nagyvállalatoknál (5. ábra) azt tapasztaltuk, hogy egyre markánsabban jelennek meg a munkahelyi egészségfejlesztő programok. Amelynek hátterében állhat, hogy az alkalmazottak számának növekedése igényli a humán erőforrással való tudatosabb gazdálkodást. A munkavállalóknak megfogalmazott javaslatokban - hasonlóan, mint a középvállalkozások esetében tapasztaltunk - a munkakörülmények javítását, a szemléletváltást és a vállalton kívüli és belüli programokat javasolják. A nagyvállalatok (három, aki javaslatot fogalmazott meg) a kormányzat felé tett javaslatként a támogatásokat fogalmazzák meg, melyek megoldást jelenthetnek az egészségfejlesztő programok szélesebb körű alkalmazásában. 


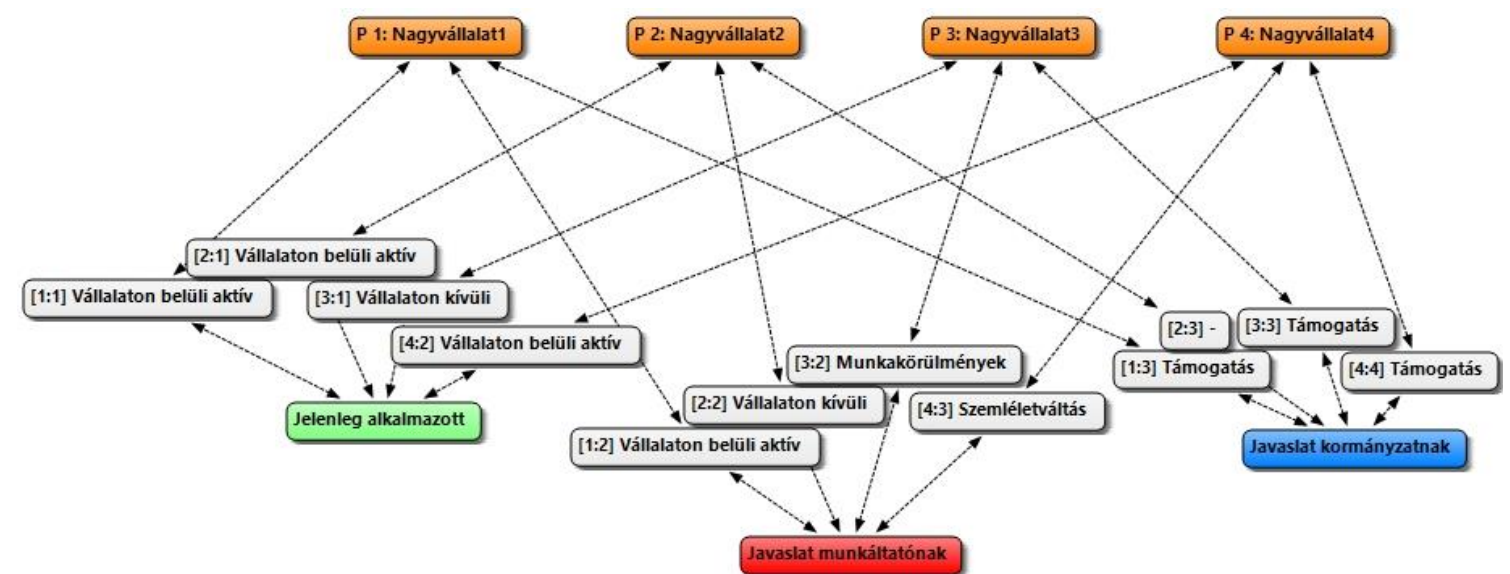

5. ábra. A nagyvállalatok körében jelenleg alkalmazott egészségfejlesztő program meglétének alakulása és az általuk megfogalmazott javaslatok a kormányzat-nak és munkavállalóknak

\section{Köveztetések és javaslatok}

Munkáltatói szegmensre fókuszáló kutatásunk során az ország több pontjáról vizsgáltunk mikrokis- közép- és nagyvállalatokat $(\mathrm{N}=41)$. Primer kutatásunk során mind kvalitatív, mind kvantitatív adatelemzést végeztünk, mely során kérdőív és mélyinterjú került kidolgozásra annak érdekében, hogy képet kapjunk a hazánkban múködő vállalatok egészséges életmódra való törekvéséről, az egészségfejlesztő programok megjelenéséről a vállalatok érdekében.

A kvantitatív adatelemzés során kiderült, hogy bár a vállalatok egységesen magas prioritásnak tartják az egészséges munkaerőt és a munkakörülményeket és a sportolást, jelenleg alkalmazott egészségfejlesztő programok és munkáltatói támogatások ehhez nem társulnak. A jövőre nézve pozitívumként jelenik meg azonban, hogy ezen a téren a felelősségvállalás mértéke növekedni látszik, a vállalatok láthatóan fontosnak tartják a jövőbeni egészségfejlesztő programok integrálását a vállalati életbe. A megkérdezett vállalatok képviselői úgy gondolják ezen kezdeményezések leginkább a munkavállalók véleményében és a betegséggel töltött napok számának csökkentésében játszanak fontos szerepet.

A mélyinterjús vizsgálat során a kitöltők közül véletlenszerűen kiválasztottunk négy vállalatot méret szerinti felosztásban, őket a jelenleg alkalmazott, jövőben tervezett egészségfejlesztő programokról és kormányzat felé intézett egészségfejlesztő javaslataikról kérdeztük.

Az eredményekből kiderült, hogy a vállalatok méretének növekedésével párhuzamosan egyre aktívabb szerepvállalás figyelhetô meg a jelenleg alkalmazott egészségfejlesztő programok tekintetében. A mikro- és kisvállalatok körében még mindig vannak olyan szervezetek, akik úgy gondolják a munkavállalók fizikai munkavégzés jellegéből fakadóan nincs szükségük a fizikai aktivitást és a sportolást ösztönző programok alkalmazására.

A jövőben megvalósítani tervezett intézkedésekből jól látszik, hogy azon vállalatok, amelyek jelenleg is támogatják foglalkoztatottjaik fizikai aktivitását, a munkakörnyezet javításával és szemléletváltásként egészséges életmódot népszerűsítő kampányokkal és tájékoztatókkal egészítenék ki kezdeményezéseiket az egészségtudatos magatartás növelése érdekében. A vállalaton belüli kezdeményezések (sportnapok, szervezett tornák, bérelt létesítmények) mellett egyre inkább megjelenik 
a vállalaton kívüli támogatási forma is (juttatások, cafetéria formájában történő egyéni edzéslehetőség támogatása). Fontos azonban, hogy a vállaltok és a munkavállalók is rendelkezzenek a szükséges információval, mely segítheti a céljaik megvalósítását (Molnár, 2019). A válaszadók általános megítélése mérettől függetlenül, hogy a kormányzat leginkább az adó egészségmegőrzésre való felhasználásával és egyéb támogatásokkal segíthetné a vállalatokat foglalkoztatottjaik egészséges életmódra való ösztönzési törekvéseikben. Ez a koncepció azért is kedvező lehet, hiszen a munkavállalók fizikai aktivitásának és sportolásának növelésével komoly megtakarításokat lehet elérni az egészségügyi kiadások területén, mely a munkaadóknak és az államnak is megtakarítást eredményezhet, azaz a munkavállalók egészségébe való befektetés, mint tôkejószág megtérül hosszú távon. Több kutatás is megerősíti, hogy a fizikai inaktivitásnak igen magas költség terhei vannak, melyek az egészségügyi kiadások területén mérhető leginkább (Gabnai et. al., 2019; Ács et.al., 2019; 2020.).

A testmozgás az egyik leginkább költséghatékony módja az egészség megőrzésének és a munkaképesség megtartásának, hiszen számos pozitív hatása van az emberi szervezetre és prevenciót képez számos népbetegséggel szemben (Lacza-Radák, 2013; Bíró et. al., 2018), így a sportoló nemzet koncepció teljesítése a munkavállalóknak, munkaadóknak és az államnak is közös érdeke, melyekhez a különböző szabadidős sportok jól felhasználhatóak (Váczi, 2015). Több kutatás is beszámol arról, hogy a rekreációs és sportszolgáltatások széles palettája megtalálható hazánkban, melynek termékkínálatának diverzifikációja jó infrastrukturális hátteret és szolgáltatást nyújthat akár a munkahelyi egészségmegőrző programokhoz, vagy a sportkártyák által kínált szolgáltatások helyszínei lehetnek (Lenténé et. al., 2018; Bíró et. al., 2019; Lenténé et. al., 2019).

\section{Köszönetnyilvánítás}

A publikáció elkészítését az EFOP-3.6.1-16-2016-00022 számú Debrecen Venture Catapult Program. c. projekt támogatta. A projekt az Európai Unió támogatásával, az Európai Szociális Alap társfinanszírozásával valósult meg.

\section{Hivatkozott források}

[1.] Dajnoki K. (2019): Kommunikáció a szervezetben: Üzenetek a szervezetben. In: Kőmíves P. M. - Pierog A - Dajnoki K. (szerk.).: Üzleti kommunikációs alapismeretek: Munkafüzet. Debrecen: Debreceni Egyetem Kiadó. 16.

[2.] Dajnoki K. (2020): A HR új irányai. In: Dajnoki K. - Kun A. I. (szerk.).: Bevezetés az emberi eróforrás menedzsmentbe. Debrecen: Debreceni Egyetem Kiadó. pp. 107-116.

[3.] Héder M. - Szabó Sz. - Dajnoki K. (2018): Effect of Labour Market Changes on HR Functions. The annals of The Faculty of Economics Subotica, 54 (39), 123-138.

[4.] Kozák A. - Dajnoki K. (2019): Dolgozói véleményék a munkaerőmegtartást célzó intézkedésekről. Taylor: Gazdálkodás- és szervezéstudományi folyóirat: A virtuális intézet Közép-Európa kutatására közleményei, 36 (2) 56-65.

[5.] Ráthonyi-Ódor K. - Ráthonyi G. - Földesi B. - Urbánné Katona M. (2017): Sportközpontú CSR-intézkedések értékelése. Acta Carolus Robertus, 7 (1), 233-247.

[6.] Gősi Zs. - Tóth D. Z. - Bukta Zs. (2020): Egyéni társadalmi felelősségvállalás lehetőségei a szabadidősportban. Magyar Sporttudományi Szemle, 85, 50. 
[7.] Staniškiene, E. - Stankevičiūte, Ž. (2018): Social sustainability measurement framework: The case of employee perspective in a CSR-committed organisation. Journal of Cleaner Production, 188, 708-719. DOI: $10.1016 /$ j.jclepro.2018.03.269

[8.] Rahdari, A. - Sepasi, S. - Moradi, M. (2016): Achieving sustainability through Schumpeterian social entrepreneurship: The role of social enterprises. Journal of Cleaner Production, 137, 347360. DOI: $10.1016 /$ j.jclepro.2016.06.159

[9.] Holmqvist, M. (2009): Corporate social responsibility as corporate social control: The case of work-site health promotion. Scandinavian Journal of Management, 25 (1), 68-72. DOI: 10.1016/i.scaman.2008.08.001

[10.] Ráthonyi-Ódor K. - Bácsné Bába É. - Müller É. - Bács Z. - Ráthonyi G. (2020): How Successful are the Teams of the European Football Elite off the Field? - CSR Activities of the Premier League and the Primera Division. International Journal of Environmental Research and Public Health, 17 (20), 31. DOI: 10.3390/ijerph17207534

[11.] Aldana S. G. - Merrill R. M. - Price K. - Hardy A. - Hager R. (2005): Financial impact of a comprehensive multisite workplace health promotion program. Preventive medicine, 40 (2), 131 137. DOI: $10.1016 /$ i.ypmed.2004.05.008

[12.] Baicker K. - Cutler D. - Song Z. (2010): Workplace wellness programs can generate savings. Health affairs, 29 (2), 304-311. DOI: 10.1377/hlthaff.2009.0626

[13.] Nyitrainé-Garaj E. (2015): Versenyképesség és egészségnyereség. A munkahelyi egészségfejlesztés értéknövelő alternatív megoldásai. Hadtudomány (Online), 25, 41-47.

[14.] Bradish, C. - Cronin J. J. (2009): Corporate social responsibility in sport. Journal of Sport Management, 23 (6), 691-697. DOI: 10.1123/jsm.23.6.691

[15.] Levermore, R. J. - Moore, N. (2015): The need to apply new theories to "sport CSR". Corporate Governance (Bingley), 15 (2), 249. DOI: 10.1108/cg-09-2014-0113

[16.] Breitbarth, T. - Walzel S. - Anagnostopoulos C. - van Eekeren, F. (2015): Corporate social responsibility and governance in sport: "Oh, the things you can find, if you don't stay behind!". Corporate Governance, 15 (2), 254-273. DOI: 10.1108/cg-02-2015-0025

[17.] Bason, T. - Anagnostopoulos, C. (2015): Corporate social responsibility through sport: a longitudinal study of the FTSE100 companies. Sport, Business and Management: An international Journal, 5 (3), 218-241. DOI: 10.1108/sbm-10-2014-0044

[18.] Heinze, K. L. - Soderstrom, S. - Zdroik, J. (2014): Social Responsibility in Professional Sport: A Case Study of the Detroit Lions. Journal of Sport Management, 28 (6), 672-686. DOI: 10.1123/jsm.2013-0307

[19.] Bjurvald, M. (2004): Från arbetarskydd till hälsofrämjande arbetsplatser. In: C. Källestål (Ed.), Hälsofrämjande arbete på arbetsplatser. Stockholm: Folkhälsoinstitutet. pp. 11-14.

[20.] Tones, K. - Tilford, S. (2001): Health promotion: Effectiveness, efficiency and equity. Cheltenham: Nelson Thornes Ltd.

[21.] Sidell, M. - Jones, L. - Katz, J. - Peberdy, A. - Douglas, J. (2003): Debates and dilemmas in promoting health. New York: Palgrave.

[22.] Seedhouse, D. (2004): Health promotion: Philosophy, prejudice and practice. Chichester: Wiley.

[23.] The European Agency for Safety and Health at Work (2004): Corporate Social Responsibility and Safety and Health at Work. Office for Official Publications of the European Communities.

[24.] Molnár E. (2019): Információ = Hatalom. Gradus 6 évf. 3. sz. 35-43.

[25.] Gabnai Z. - Müller A. - Bács Z. - Bácsné Bába É. (2019): A fizikai inaktivitás nemzetgazdasági terhei. Egészségfejlesz̨tés, 60 (1), 20-30.

[26.] Ács P. - Paár D. - Melczer Cs. - Fodor-Mazzag K. (2019): A mozgás a legolcsóbb gyógyszer - A fizikai inaktivitás költsége az egészségügyben: A Fizioterápiás és Sporttudományi Intézet 
által fejlesztett új motivációk implementációja. In: Oláh A. - Molics B. - Ács P. - Kránicz J. - Járomi M. - Hock M. - Császár G. - Leidecker E. - Bohner-Beke A. - Kovácsné Bobály V. (szerk.). 20 éves a pécsi gyógytornász képzés (1999-2019): Jubileumi emlékülés és sqakmai továbbképzési konferencia. Pécs: Pécsi Tudományegyetem Egészségtudományi Kar. 17.

[27.] Ács P. - Kovács A. - Paár D. - Hoffbauer M. - Szabó P. - Szabó T. - Stocker M. (2020): Comparative analysis of the economic burdens of physical inactivity in Hungary between 2005 and 2017. BMC Public Health, 20 (1), 1165- 1174. DOI: 10.1186/s12889-020-08478-y

[28.] Lacza Gy. - Radák, Zs. (2013): Elixír-e a testedzés? Orvosi Hetilap, 154 (20), 764-768.

[29.] Biró M. - Pucsok J. M. - Hidvégi P. - Tatár A. - Lenténé Puskás A. (2018): Az Észak-alföldi régió lakosságának egészségi állapota - a mozgás potenciálja. In: Balogh L. (szerk.): Fókusz̧ban az egészség. Debrecen: Debreceni Egyetem Sporttudományi Koordinációs Intézet. pp. 61-72.

[30.] Váczi P. (2015): Szabadidősport. In: Váczi P. (szerk.): Szabadidősportok. Eger: EKF Líceum Kiadó. pp. 5-21.

[31.] Lenténé Puskás A. - Hidvégi P. - Tatár A. - Pucsok J. M. - Biró M. (2018): Recreational potential of the northern great plain region in Hungary. In: Jaromír, Š. - B. Dobay (szerk.): Sport science in motion: proceedings from the scientific conference. Komárno: Univerzita J. Selyeho. pp. 218-226.

[32.] Biró M. - Pucsok J. M. - Hidvégi P. - Molnár A. - Mikhárdi S. - Lenténé Puskás A. (2019): A magyarországi és az Észak- alföldi fürdők jellemzőinek, forgalmának és a fürdők által nyújtott szolgáltatásoknak az elemzése. In: Balogh L. (szerk.) Sport és társadalom. Debrecen: Debreceni Egyetem Sporttudományi Koordinációs Intézet. pp. 18-28.

[33.] Lenténé Puskás A. - Hídvégi P. - Pucsok J. M. - Dobay B. - Molnár A. - Bíró M. (2019): A szabadidős sport keresleti és kínálati elemek vizsgálata az Észak-alföldi régió egészségturizmusában. Különleges Bánásmód, 5 (4), 45-54.

\section{Szerzők}

Molnár Anikó

Sportközgazdász Msc

Debreceni Egyetem

Sportgazdasági- és Menedzsment Intézet

miller.e.annie@gmail.com

Dr. Müller Anetta

egyetemi docens

Debreceni Egyetem

Sportgazdasági- és Menedzsment Intézet

muller.anetta@econ.inudeb.hu 